\title{
Effects of Trigonella foenum graecum L. seeds on liver structure, liver function biomarkers and some hematological and some physiological parameters in rats
}

\author{
A. A. Abdel Hamid 1,* \\ ${ }^{1}$ Department of Animal Production, Faculty of Agriculture, Al-Azhar University, Nasr City, Cairo, Egypt \\ *Correspondence: Abdelhamidabdallah78@azhar.edu.eg (A. Abdel Hamid)
}

\begin{abstract}
This experiment aimed to evaluate the effect of different levels of Trigonella foenum graecum on liver structure and functions and some physiological and hematological parameters in normal male albino rats. A total of 24 male albino rats were used and divided into four groups (6 rats per group). The first group G1 was control group, G2 rats fed normal diet $+2.5 \%$ Trigonella foenum graecum, G3 rats fed normal diet $+5 \%$ Trigonella foenum graecum and G4 rats fed normal diet $+7.5 \%$ Trigonella foenum graecum. Blood samples were collected after 4 and 8 weeks from the start of the experiment. At the end of the experiment, rats were sacrificed to obtain the livers. Results indicated that Treatment of rats with 7.5\% Trigonella Foenum graecum for 8 weeks significantly increased blood platelets. Treatment of rats with $2.5 \%$ Trigonella foenum graecum did not show any significant effect on liver function (activities of ALT and AST), serum total protein and albumin Meanwhile 5\% or 7.5\% Treigonella foenum graecum significantly increased ALT and AST activities. The results also showed that Treatment of rats with $5 \%$ or $7.5 \%$ Trigonella foenum graecum for 8 weeks caused mild ischemic changes of liver hepatocytes. It could be concluded that $2.5 \%$ Trigonella foenum graecum is safe to be used for 8 weeks without any adverse side effects on liver structure and function.
\end{abstract}

Keywords: Liver structure; Hematology; Histopathological changes.

\section{INTRODUCTION}

The vegetation on the earth is a perennial and renewable source of food and energy which is necessary for the survival of most organisms. Plants are the green factors of our planet; they convert carbon dioxide and water to carbohydrates; and nitrogen to amino acids. Besides food, plants are considered to be the nature's green pharmacy, which provide drugs to maintain the good health and to restore the failing health of humans. The medicinal arts had its origin when mankind first began to use remedial measures to get rid of their pains, sufferings and other illnesses, by using healing potions prepared from plants. Thus, from the tribal medicines and folk medicines, we have reached the modern era of sophisticated synthetically made drugs. The medicines of the ancients' civilization and cultures were mostly associated with plants Badr et al. (2012).

Trigonella foenum graecum (T.F) seeds are rich in protein, fat, total carbohydrates and minerals such as calcium, phosphorus, iron, zinc and magnesium (Gupta et al., 1996) and contains active constituents such as alkaloids, flavonoids, steroids and saponins (kor and Zadeh 2013). Trigonella foenum graecum is one of the most widely used medicinal plants in folk medicine (subramanion and prasath 2014). Trigonella foenum graecum contains phenolic and flavonoid compounds which help to enhance antioxidant capacity (Srinivasan, 2006). The objectives of this study are to investigate the effects of different level of Trigonella foenum graecum as feed additives on some hematological, physiological and liver structure in male albino rats.

\section{MATERIALS AND METHODS}

The present study was carried out at the Animal House of Animal Production Department Faculty of Agriculture, AlAzhar University, Cairo, Egypt.

\section{Animals}

A total number of 24 male albino rats obtained from El Osman farm, Cairo, Egypt Animals housed in stainless cages and provided feed and water ad libitum. All animals were healthy and clinically free of diseases. Animals housed in cages where the mean ambient temperature ranged from 27 and to $31^{\circ} \mathrm{C}$.

\section{Experimental Design}

Trigonella foenum graecum seeds were used in the present study. Seeds of Trigonella foenum graecum were obtained from the local market in Cairo. The study included 24 adult male albino rats and divided randomly into 4 equal groups ( 6 rats each) as the Following: Group 1: rats fed normal diet (control) Group 2: rats fed normal diet $+2.5 \%$ Trigonella foenum graecum Group 3: rats fed normal diet $+5 \%$ Trigonella foenum graecum Group 4: rats fed normal diet $+7.5 \%$ Trigonella foenum graecum Rats treated with experimental diets for 8 weeks. 


\section{Blood sampling}

Blood samples were collected from all rats by with drawing blood from the orbital venous plexuses using a capillary tube. Samples collected after 4 and 8 weeks from the start of the experiment. Blood samples were collected and divided into two tube. The first tube contains heparin to obtain fresh blood for hematological parameters. The second tube bloods were centrifuged at $3000 \mathrm{rpm}$ for $15 \mathrm{~min}$ to obtain serum which transferred to Eppendorf tubes and stored at $-20^{\circ} \mathrm{C}$. until subsequent analysis.

\section{Histological study}

At the end of the experiment, rats were sacrificed to obtain their livers. Immediately after extraction, the livers were immersed in formalin $10 \%$ for two days, washed in water, dehydrate in ascending grade of ethyl alcohol and finally cleared by xylene and embedded in melted paraffin wax. The livers were sectioned at six-micron thickness and stained by eosin and heamatoxylin according to Pearse (1968).

\section{Hematological parameters}

Hemoglobin, RBCs, platelets and WBC differentiation were determined using Electronic DIAGON method according to (D-cell 60).

\section{Serum parameters}

Serum AST and ALT activities was determined by using a quantitative colorimetric method of Schumann and Klauke (2003). Serum total protein was measured using kits depending on the method of Burtis et al. (2007). Serum albumin was determined using colorimetric method according to Gindler and Westgard (1973).

\section{Statistical analysis}

Data subjected to analysis of variance using General Linear Model's procedure of SPSS software program package (SPSS, 2011) All percentages were transformed to arcsine then analyzed to approximate normal distribution before ANOVA. In addition, significant differences among means were determined by Duncan's multiple rang test (Duncan, 1955) at 5\% level of significance. Data were analyzed by oneway analysis method.

\section{RESULTS AND DISCUSSION}

\section{Hematological parameters (RBCs and Hemoglobin)}

Table (1) shows that treatment of rats with Trigonella foenum graecum (2.5, 5 and 7.5 $\%$ ) for 8 weeks did not show any significant effect on blood RBCs and Hemoglobin platelets.

Table (1) also shows that treatment of rats with 7.5 Trigonella foenum graecum for 8week significant increased blood platelets. The results also show that 5\% Trigonella foenum graecum increased blood platelets but the increased were not significant. Treatment of rats with $2 \%$ Trigonella foenum graecum did not show any significant effect on blood platelets. The above results indicated that blood platelets were increased by increasing the dose of Trigonella foenum graecum.

\section{White blood cells (WBCs)}

Table (1) shows that treatment of rats with Trigonella foenum graecum $(2.5,5$ and 7.5 $\%$ ) for 8 weeks did not show any significant effect on blood WBCs, Neutrophils, lymphocytes and monocytes. Khalil (2004) showed that there were Non- significant change of white blood cell at 4-weeks by alloxan treatment was detected Rats treated by fenugreek extract displayed nonsignificant variation from the corresponding control after month in $\mathrm{RBCs} \mathrm{Hb} \%$ and in WBCs. Fenugreek treated diabetic displayed non-significant alternation in $\mathrm{RBCs}, \mathrm{Hb} \%$ and in WBCs comparable to control. AlMashhadani (2017) Showed that WBC count significantly decreased in fenugreek seeds but there were no statistical differences in control, fenugreek leaves when compared with $\mathrm{CC} 14$ treated rats. He also reported that the rats treated with fenugreek significantly decreased WBC and PLT when compared with CC14 treated rats.

\section{Serum parameters}

\section{Serum total protein and albumin}

Tables 2 and 3 showed that treatment of rats with Trigonella foenum graecum $(2.5,5$ and $7.5 \%$ ) for 4 or 8 weeks did not show any significant effect on serum total proteins and albumin.

These results are similar to those reported by Elmahdi and El-Bahr (2015) who reported 
that dietary supplementation with 5 or $10 \%$ Trigonella foenum graecum to rats fed high cholesterol diet did not show any significant effect on serum total protein and albumin. Khalil (2004) reported that non diabetic rats treated with fenugreek recorded nonsignificant increase in serum total protein, albumin and globulin compared with the control ones.

On the other hand, Zeweil et al. (2015) indicated that treatment of growing rabbits with fenugreek and Anise seed significantly increased serum total protein, albumin and globulin as compared with the control group. Bhandari et al. (1997) showed that oral treatment with ethanolic extract of fenugreek seeds $(200 \mathrm{mg} / \mathrm{kg}$ daily) for 20 days raised the serum protein and albumin.

Rashwan (1998) showed that the addition of fenugreek to New Zealand white doe rabbit's diet decreased serum total protein. Badr (2006) reported that treatment of rats with $2 \%$ fenugreek insignificantly decreased plasma total protein in both seasons (summer and winter), meanwhile $4 \%$ fenugreek caused a significant decrease in plasma total protein only during winter season. He also reported that these effects were due mainly to the decrease in plasma globulin. While no significant changes occurred in plasma albumin. This conflict might be attributed to the different dose, plant preparation, and route of administration and time of the experiment.

\section{Serum ALT and AST activities}

Tables 4 and 5 showed that treatment of rats with $2.5 \%$ Trigonella foenum graecum for 4 or 8 week did not show any significant effect on serum ALT and AST activities. Meanwhile treatment of rats with 5 or $7.5 \%$ Trigonella foenum graecum for 4 or 8 weeks significantly increased serum ALT and AST activities. Rao et al. (1996) found that fenugreek seeds (5, 10 and $20 \mathrm{~g} \%$ of diet) in rats led no significant effect on (AST, ALT) activities of liver function enzymes.

Badr (2006) showed that medicinal plants (fenugreek, Nigella sativa or garlic) at a dose of $2 \%$ or $4 \% \mathrm{mg} / \mathrm{kg}$ diet did not show any significant effect on plasma GOT and GPT during summer or winter seasons as compared with the control group.

Ali (2004) reported that Trigonella foenum graecum and Nigella sativa had no significant effect on plasma transaminases activities (AST and ALT) in both seasons (summer and winter) as compared with the control group.

Sherlock and Dooley (1997) stated that the AST (GOT) is a mitochondrial enzyme present in large quantities in heart, liver, skeletal muscle and kidney and its serum level increases whenever these tissues are acutely destroyed presumable due to release from damaged cells. Meanwhile the ALT (GPT) is a cytosolic enzyme also present in liver, although the absolute amount is less than that of AST, a greater proportion of ALT is present in liver compared with heart and skeletal muscle. A serum increase is therefore more specific for liver damage that AST.

\section{Histopathological changes of the liver}

The liver structure of the control and 2.5\% Trigonella foenum graecum groups showed preserved lobular architecture. The portal tracts consisted of normal hepatic artery, portal vein and bile duct. The central veins were normal. The hepatocytes were normal in arrangement of cytoplasm and nuclei (Fig 1 and 2) Liver feature in 5\% and 7.5\% Trigonella foenum graecum groups showed preserved lobular architecture. The portal tracts consisted of normal hepatic artery, portal vein and bile duct. The hepatocytes reveal mild ischemic changes of cytoplasm and normal nuclei and normal hepatic sinusoids (Mild ischemic changes of hepatocytes) (Fig. 3 and 4).

Elevation in liver function enzymes by fenugreek treatment as well as (Duke, 1985) \& Kapoor (1990) recorded that fenugreek has no inflammatory disorder in liver.

\section{CONCLUSION}

It could be concluded that $2.5 \%$ Trigonella foenum graecum is safe to be used for 8 weeks without any adverse side effects on liver structure and function. The results also suggest that it is worth while carrying out further studies to find out whether the high dose of Trigonella foenum graecum or its extract could be supplemented to diet or not.

\section{REFERENCES}

Al-Mashhadani, F.A., 2017. Effect of fenugreek seed and leaves on some hematological and biochemical parameters in CC14.-induced liver injury. Int. J. Curr. Microbiol. App. Sci. 6 (4), 2328-2337. 
Ali, M.A.M., 2004. The Role of Medicinal Plants on the Cardiovascular System in Rats. Ph.D. Thesis, Department of Animal production, Faculty of Agriculture Al-Azhar University, Cairo.

Badr, M.I., 2006. Effects of Energy and Protein Levels in Diets and Some Medicinal Plants on Plasma Insulin and Glucose Levels in Rats. Ph.D. Thesis, Department of Animal Production, Faculty of Agriculture Al-Azhar University, Cairo.

Badr, M.J., Khalifa, H.H., Abd El Hamid, A.A., Khalil, M.H., El Koatb, A.F.M., 2012. Protective effect of some medicinal plants on blood parameters, kidney and liver function and histopathogical features of kidney in rats. Egypt. J. Anim. prod. 49 (2), 233-240.

Bhandari, U., Sharma, J.N., Grover, J.K., 1997 Effect of ethanolic extract of fenugreek seeds on hyperglycaemic rats. Asia Pac. J. Pharmacol. 12 (3-4), 117-119.

Bin-Hafeez, B., Haque, R., Parvez, S., Pandy, S., Sayeed, I., Raisuddin, S., 2003. Immunomdulatory effects of fenugreek (Trigonella foenum graecum L.) extract in mice. Int. Immunopharmacol. 3 (2), 257-277.

Blumenthal, M., Goldberg, A., Brinckmann, J., 2000. Herbal Medicine Expanded Commission American Botanical Council Integrative Medicine Communications; MA, P. 130.

Burtis, C.A., Ashwood, E.R., Bruns, D.E., 2007. Tietz Fundamentals of Clinical Chemistry 6th Edition, Saunders Elsevier, St. Louis, MO.

Duck, J.A., 1985. Handbook of Medicinal Herbs, CRC Press; Boca Raton, FL.

Elmahdi, B., El-Bahr, S.M., 2015. Influence of dietary supplementation of fenugreek (Trigonella foenum graecum) on serum biochemical parameters of rats fed high cholesterol Diet Int. J. Biol. Chem. 9 (1), 1-10.

Gindler, E.M., Westgard, J.O., 1973. Automated and manual determinations of albumin with bromocreosol green and a new surfactant. Clin. Chem. 6, 4A.

Duncan, B.D., 1955. Multiple range and multiple F Test. Biometrics. 11, 1-42.

Gupta, K., Thakral, K.k., Arora, S.K., Chowdhary, M.I., 1996. Structural carbohydrate and mineral seeds. Ind. Coca. Arecenut Species J. 13, 127-129.
Kapoor, L.D., 1990. Handbook of Arurvedic Medicinal plants, CRC Press, Boca Raton, FL.

Khalil, E.A.M., 2004. Biochemical and histopathological studies on the influence of agueous extract of fenugreek seed (Trigonella foenum graecum) on alloxan diabetic make rats. Egypt. J. Hospital Med. 15, 83-94.

Kor, Z.M., Zadeh, G.B., 2013. Fenugreek (Trigonella foenum graecum L.) as a valuable medicinal plant. Int. J. Adv. Biol. Biomed. Res. 1 (8), 922931.

Pearse, A.G.E., 1968. Histochemistry; In: Theoretical and Applied, 3rd Edition. Churchill Living Stone, New York, PP. 613-658.

Rao, P.U., Sesikeran, B., Rao, P.S., Nadiu, A.N., Rao, V.V., Ramachondran, E.P., 1996. Short term nutritional and safety evaluation of fenugreek. Nutr. Res. 16 (9), 1495-1505.

Rashwan, A.A., 1998. Effects of dietary addition of anise, Fenugreek and caraway on reproductive and productive performance of New Zealand White rabbit does. Egypt. J. Rabbit Sci. 8 (2), 157-167.

Schumann, G., Klauke, R., 2003. New IFCC reference procedures for the determination of calalytic activity concentration of five enzymes in serum: preliminary upper reference limits obtained in hospitalized subjects. Clin. Chem. Acta. 327, 6979.

Sherlock, S., Dooley, J., 1997. Diseases of the liver and bilary system 10th Edition. Black well, London, Edinburgh, pp: 19-21.

SPSS. 2011. IBM SPSS Statistics for Windows, release 20.0.0. Chicago, IL.

Srinvasan, K., 2006 Fenugreek (Trigonella foenum graecum) a review of heath beneficial effects. Food Rev. Int. 22, 203-224.

Subramanian, S.P., Prasath, G.S., 2014. Trigonelline improves insulin sensitivity and modulates glucose homeostasis in high fat fedstreptozotocin induced type 2 diabetic rats. J. Pharm. Res. 8 (4), 563-569.

Zeweil, H.S., Zahran, S.M., Abd El-Rahman, M.H., Embark, J., 2015. Effect of fenugreek and anise seeds as natural growth promoter on the performance, carcass, blood constituents and antioxidant status of growing rabbits. Egypt. Poult. Sci. 35, 909-921. 


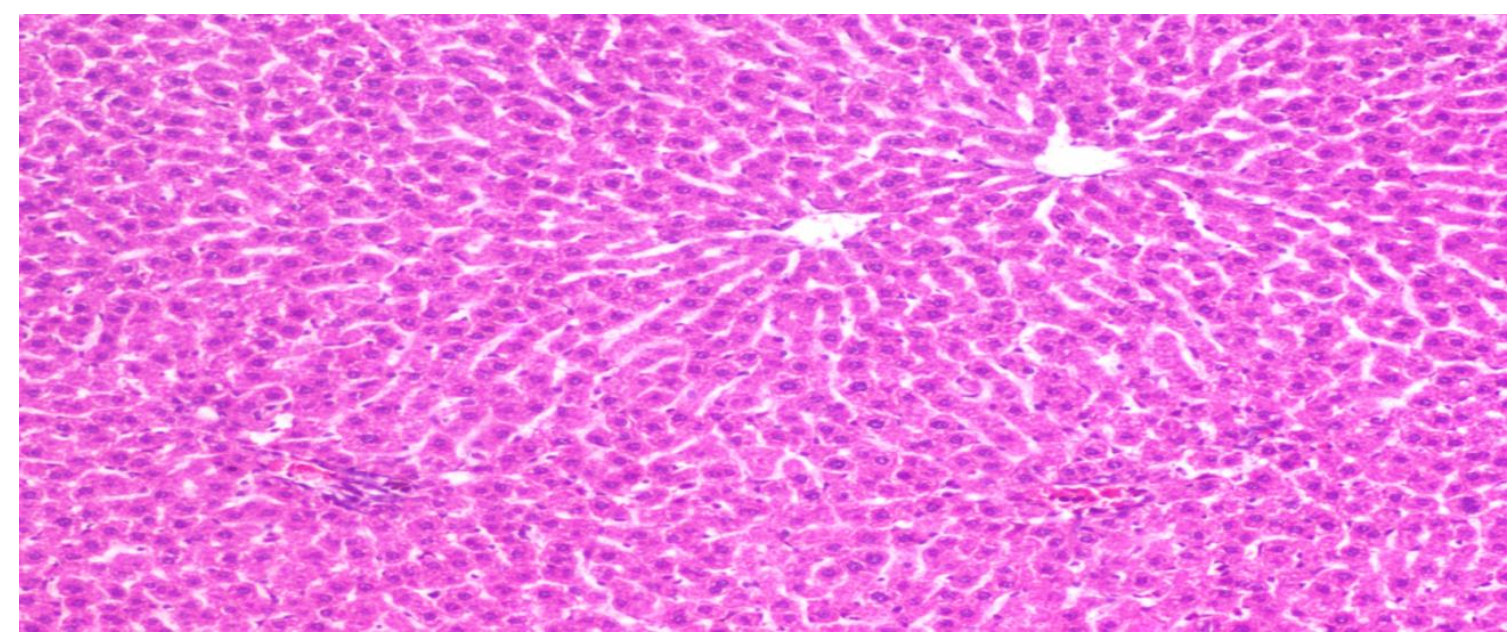

Fig. 1. Sections in the Liver tissue of control group showed preserved lobular architecture. The portal tracts consisted of normal hepatic artery, portal vein and bile duct. The central veins, were normal. The hepatocytes were normal in arrangement of cytoplasm \& nuclei. (H\& E., stain, x100).

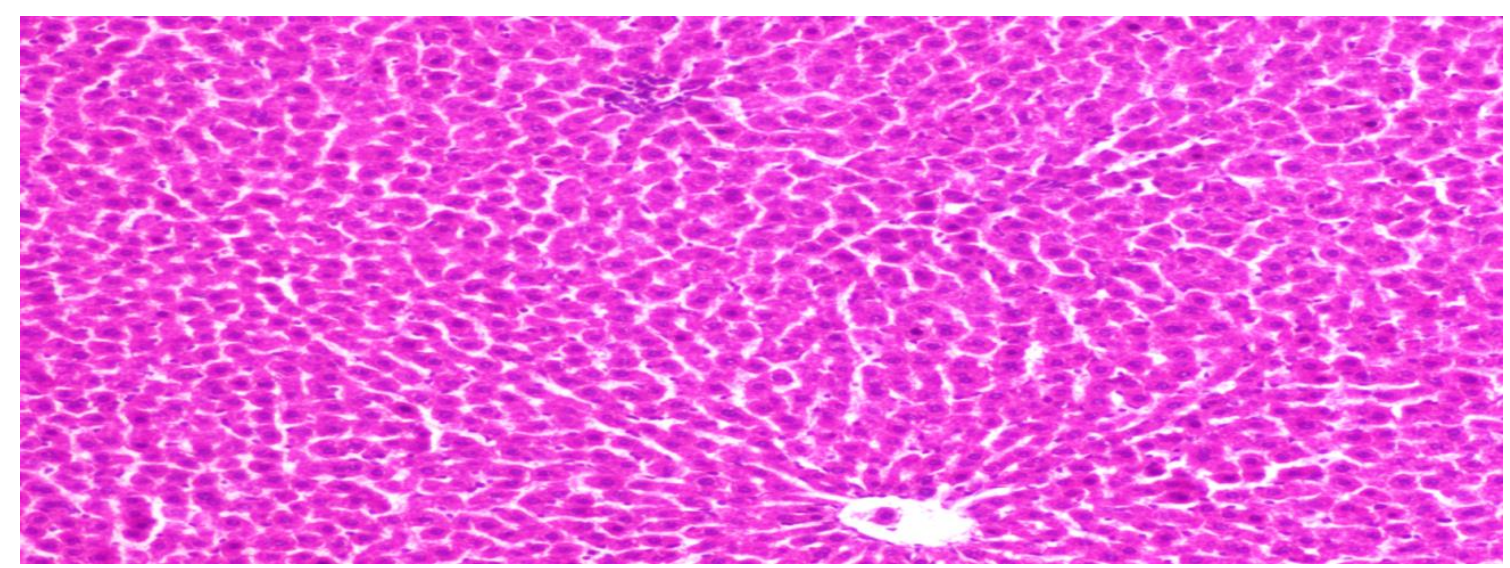

Fig. 2. Sections in the Liver tissue of $2.5 \%$ Trigonella foenum graecum showed preserved lobular architecture. The portal tracts consisted of normal hepatic artery, portal vein and bile duct. The central veins, were normal. The hepatocytes were normal in arrangement of cytoplasm \& nuclei. (H \& E., stain, x100). 


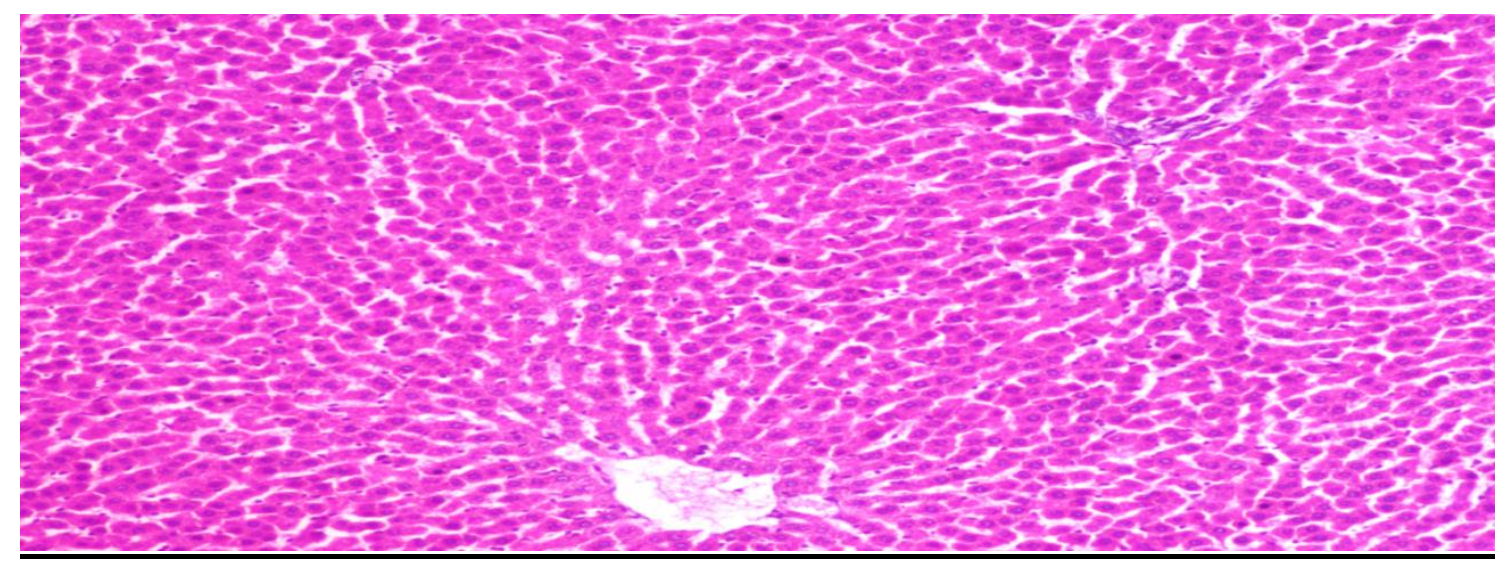

Fig. 3. Sections in the Liver tissue of 5\% Trigonella foenum graecum showed preserved lobular architecture. The portal tracts consisted of normal hepatic artery, portal vein and bile duct. The hepatocytes reveal mild ischemic changes of cytoplasm and normal nuclei and normal hepatic sinusoids. (H \& E., stain, x100). (Mild ischemic changes of hepatocytes).

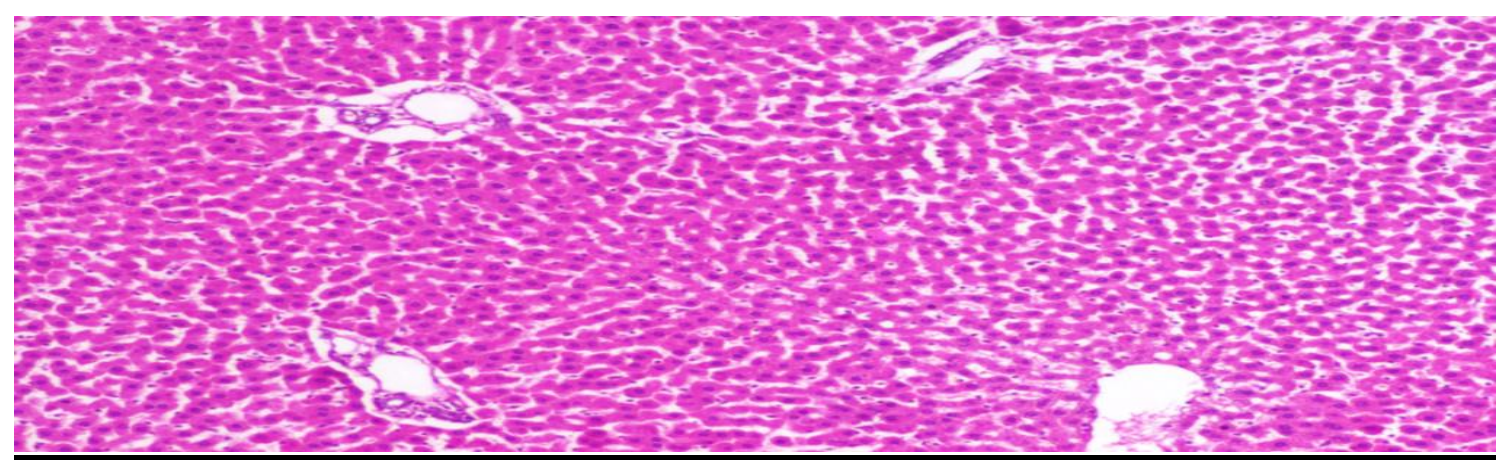

Fig. 4. Sections in the Liver tissue of $7.5 \%$ Trigonella foenum graecum showed preserved lobular architecture. The portal tracts consisted of normal hepatic artery, portal vein and bile duct. The hepatocytes reveal mild ischemic changes of cytoplasm and normal nuclei and normal hepatic sinusoids. (H \& E., stain, x100). (Mild ischemic changes of hepatocytes). 
Table 1. Mean \pm S.E. for the effect of Trigonella foenum graecum seeds on hematological parameters.

\begin{tabular}{|c|c|c|c|c|c|c|c|c|c|c|c|c|c|c|}
\hline Item & & & & & & Haen & gical para & & & & & & & \\
\hline Group & $\begin{array}{c}\mathrm{Hb} \\
(\mathrm{g} / \mathrm{dL})\end{array}$ & Dt & $\begin{array}{l}\mathrm{RBCs} \\
\left(\mathrm{mm}^{3}\right)\end{array}$ & $\mathrm{Dt}$ & $\begin{array}{l}\text { Platelets } \\
\left(\mathrm{mm}^{3}\right)\end{array}$ & Dt & $\begin{array}{l}\text { WBCs } \\
\left(\mathrm{mm}^{3}\right)\end{array}$ & $\mathrm{Dt}$ & $\begin{array}{c}\text { Neutrophils } \\
(\%)\end{array}$ & Dt & $\begin{array}{l}\text { Lymphocytes } \\
(\%)\end{array}$ & Dt & $\begin{array}{c}\text { Monocytes } \\
(\%)\end{array}$ & $\mathrm{Dt}$ \\
\hline & 14.56 & & 5653333.33 & & 540666.66 & & 12466.66 & & 24.66 & & 62.66 & & 10.66 & \\
\hline $\mathrm{G} 1=$ Control & $\begin{array}{c} \pm \\
0.98\end{array}$ & A & $\begin{array}{c} \pm \\
539948.55\end{array}$ & A & $\begin{array}{c} \pm \\
10651.03\end{array}$ & B & $\begin{array}{c} \pm \\
2215.35\end{array}$ & A & $\begin{array}{c} \pm \\
5.69\end{array}$ & A & $\begin{array}{c} \pm \\
6.35\end{array}$ & $\mathrm{~A}$ & $\begin{array}{c} \pm \\
1.66667\end{array}$ & A \\
\hline & 14.63 & & 5730000.00 & & 558000.00 & & 18866.66 & & 17.33 & & 70.00 & & 11.33 & \\
\hline $\begin{array}{c}\mathrm{G} 2=\text { Trigonella foenum graecum } \\
2.5 \%\end{array}$ & $\begin{array}{c} \pm \\
0.86\end{array}$ & A & $\begin{array}{c} \pm \\
1300461.45\end{array}$ & A & $\begin{array}{c} \pm \\
62692.37\end{array}$ & B & $\begin{array}{c} \pm \\
3036.62\end{array}$ & A & $\begin{array}{c} \pm \\
3.84\end{array}$ & A & $\begin{array}{c} \pm \\
2.88\end{array}$ & $\mathrm{~A}$ & $\begin{array}{c} \pm \\
1.45\end{array}$ & A \\
\hline $\begin{array}{c}\mathrm{G} 3=\text { Trigonella foenum graecum } \\
5 \%\end{array}$ & $\begin{array}{c}14.80 \\
\pm \\
0.62\end{array}$ & A & $\begin{array}{c}5790000.00 \\
\pm \\
969690.67\end{array}$ & A & $\begin{array}{c}761666.66 \\
\pm \\
135126.27\end{array}$ & $\mathrm{AB}$ & $\begin{array}{c}18166.66 \\
\pm \\
4276.42\end{array}$ & A & $\begin{array}{c}15.66 \\
\pm \\
3.17\end{array}$ & A & $\begin{array}{c}73.66 \\
\pm \\
5.36\end{array}$ & $\mathrm{~A}$ & $\begin{array}{c}9.00 \\
\pm \\
1.52\end{array}$ & $\mathrm{~A}$ \\
\hline $\begin{array}{c}\mathrm{G} 4=\text { Trigonella foenum graecum } \\
7.5 \%\end{array}$ & $\begin{array}{c}13.53 \\
\pm \\
0.89 \\
\end{array}$ & A & $\begin{array}{c}5826666.66 \\
\pm \\
614120.87 \\
\end{array}$ & A & $\begin{array}{c}892333.33 \\
\pm \\
88083.92 \\
\end{array}$ & A & $\begin{array}{c}17766.66 \\
\pm \\
1146.49 \\
\end{array}$ & A & $\begin{array}{c}19.00 \\
\pm \\
6.11 \\
\end{array}$ & A & $\begin{array}{c}69.33 \\
\pm \\
7.05 \\
\end{array}$ & A & $\begin{array}{c}9.66 \\
\pm \\
1.33 \\
\end{array}$ & A \\
\hline
\end{tabular}

S.E: Standard error.

d.t: Duncan's multiple range test between groups.

Means with the same letter are not significantly different. 
Table 2. Mean \pm S.E. for the effect of Trigonella foenum graecum seeds on serum total protein concentrations $(\mathrm{g} / \mathrm{dL})$.

\begin{tabular}{lllllll}
\hline Time & 4 Weeks & & \multicolumn{3}{c}{ 8 Weeks } \\
Groups & Mean & S.E & d.t & Mean & S.E & d.t \\
\hline G1= Control & 5.49 & 0.12 & A & 6.39 & 0.41 & A \\
G2= Trigonella foenum graecum 2.5\% & 5.29 & 0.23 & A & 5.88 & 0.59 & A \\
G3= Trigonella foenum graecum 5\% & 5.05 & 0.69 & A & 5.28 & 0.84 & A \\
G4= Trigonella foenum graecum 7.5\% & 5.48 & 0.61 & A & 6.41 & 0.33 & A \\
\hline
\end{tabular}

S.E: Standard error.

d.t: Duncan's multiple range test between groups.

Mean with the same letter are not significantly different.

Table 3. Mean \pm S.E. for the effect of Trigonella foenum graecum seeds on serum albumin concentrations $(\mathrm{g} / \mathrm{dL})$.

\begin{tabular}{|c|c|c|c|c|c|c|}
\hline \multirow[t]{2}{*}{ Item } & \multicolumn{6}{|c|}{ Time } \\
\hline & 4 Weeks & & & 8 Week & & \\
\hline Groups & Mean & S.E & d.t & Mean & S.E & d.t \\
\hline G1 $=$ Control & 2.77 & 0.20 & A & 2.89 & 0.16 & A \\
\hline $\mathrm{G} 2=$ Trigonella foenum graecum $2.5 \%$ & 3.12 & 0.27 & A & 3.21 & 0.25 & $\mathrm{~A}$ \\
\hline G3= Trigonella foenum graecum $5 \%$ & 3.13 & 0.59 & A & 3.37 & 0.59 & A \\
\hline G4= Trigonella foenum graecum $7.5 \%$ & 3.01 & 0.49 & A & 3.40 & 0.08 & A \\
\hline
\end{tabular}

S.E: Standard error.

d.t: Duncan's multiple range test between groups.

Means with the same letter are not significantly different.

Table 4. Mean \pm S.E. for the effect of Trigonella foenum graecum on serum ALT (GPT) concentrations $(\mathrm{U} / \mathrm{L})$.

\begin{tabular}{lllllll}
\hline Time & 4 Weeks & & & & & \\
Groups & Mean & S.E & d.t & Mean & S.E & d.t \\
& & & & & & \\
\hline G1= Control & 22.33 & 3.33 & B & 24.66 & 1.66 & B \\
G2= Trigonella foenum graecum 2.5\% & 25.66 & 3.84 & B & 24.00 & 2.08 & B \\
G3= Trigonella foenum graecum 5\% & 33.66 & 3.28 & A & 35.00 & 0.57 & A \\
G4= Trigonella foenum graecum 7.5\% & 36.66 & 3.75 & A & 36.00 & 11.54 & A \\
\hline
\end{tabular}

S.E: Standard error.

d.t: Duncan's multiple range test between groups.

Means with the same letter are not significantly different. 
Table 5. Mean \pm S.E. for the effect of Trigonella foenum graecum on serum AST (GOT) concentrations (U/L).

\begin{tabular}{lcccccc}
\hline Time & 4 Weeks & \multicolumn{5}{c}{8 Weeks } \\
Groups & Mean & S.E & d.t & Mean & S.E & d.t \\
\hline G1= Control & 68.00 & 2.64 & B & 64.00 & 2.57 & B \\
G2= Trigonella foenum graecum 2.5\% & 71.33 & 3.92 & B & 66.66 & 3.17 & B \\
G3= Trigonella foenum graecum 5\% & 80.33 & 4.48 & A & 84.66 & 2.60 & A \\
G4= Trigonella foenum graecum 7.5\% & 81.33 & 4.09 & A & 85.66 & 2.40 & A \\
\hline
\end{tabular}

S.E: Standard error.

d.t: Duncan's multiple range test between groups.

Means with the same letter are not significantly different. 


\section{تاثيرات الحلبة على تريب ووظائف الكبد وبعض قياسات الدم والقياسات الفسيولوجية في الفتران}

عبد الميد عبد الله عبد الميمد المبيد

' مسم الانتاج الحيواني، كلية الزراعة بالقاهرة، جامعة الازهر ، مدينة نصر، القاهرة، مصر

\section{الملخص العريي}

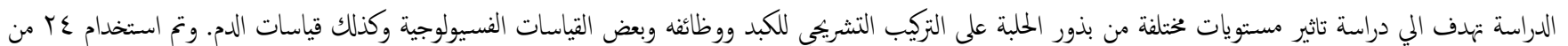

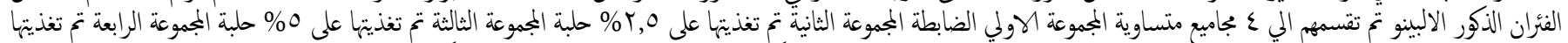

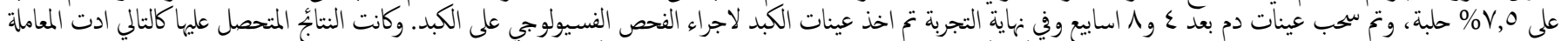

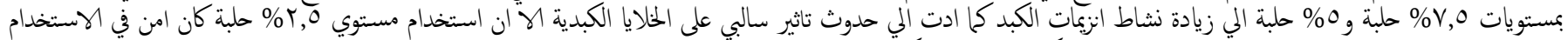
وذلك لفترات طوياة بدون اي اثار جانية على وظائف او التركب التشريكي للكبد. 